Int. Archs Allergy appl. Immun. 1986;81:287

\title{
Books Received at the Editorial Office
}

\section{J. Celis, A. Graessmann}

Cell Transformation, Series A:

Life Sciences, vol. 94 Plenum Press, New York 1985 IX + 321 pp.; US\$52.50 ISBN 0-30642082-1

Niels Mygind Essential Allergy

An Illustrated Text for Students and Specialists Blackwell Scientific, Oxford 1986 X+480pp.;E 16.50 ISBN 0-632-01188-2

\section{M.S. Mitchell (ed.)}

The Modulation of Immunity

Int. Encyclopedia of Pharmacology and Therapeutics, Section 115 Pergamon Press, Oxford 1985 X+478 pp.; USS 130.00 ISBN 0-08-031977-7

L.M. Lichtenstein, A.S. Fauci

Current Therapy in Allergy, Immunology and Rheumatology

1985-1986

Blackwell Scientific, Oxford 1985 X + 272pp.;E44.- ISBN 0-941158-48-9 